\title{
METAMORFÓZY KRESŤANSTVA NA KAUKAZE: OD JEHO ROZŠÍRENIA PO ZAČLENENIE REGIÓNU K RUSKÉMU IMPÉRIU V 19. STOROČÍ
}

\author{
Metamorphosis of Christianity in the Caucasus: From Its Expansion \\ to the Integration of the Region to the Russian Empire in the 19th Century
}

\author{
Michal Šmigel' - Aleksandr A. Cherkasov - Miroslav Kmet'
}

DOI: 10.17846/CL.2019.12.2.80-97

\begin{abstract}
MIGEL', Michal - CHERKASOV, Aleksandr A. - KMEŤ, Miroslav. Metamorphosis of Christianity in the Caucasus: From Its Expansion to the Integration of the Region to the Russian Empire in the 19th Century. Christianity in the Caucasus - from its expansion in the 3rd - 4th centuries to the integration of the region to the Russian Empire in the 19th century went through peculiar metamorphic changes. It had its own history for each nation of the region. On the one hand, old Transcaucasian cultures (Armenian and Georgian) entirely adopted Christianity and maintained it throughout the centuries. On the other hand, the mountain dweller nations of the Caucasus, lacking their own statehood, have only partially adopted Christianity with the long-term presence of religious syncretism (mix of paganism, Judaism, Christianity and Mohammedanism) and after all, they were mostly islamized. Beside a number of internal and external influences and factors, the mental conservatism of Caucasian ethnic groups also appears important in these processes.
\end{abstract}

Keywords: paganism, Judaism, Christianity, syncretism, Islam, Caucasian nations, Muhacir, Russian Empire

Abstrakt: ŠMIGEL', Michal - CHERKASOV, Aleksandr A. - KMEŤ, Miroslav. Metamorfózy krestanstva na Kaukaze: od jeho rozšírenia po začlenenie regiónu k Ruskému impériu v 19. storočí. Krestanstvo na Kaukaze - od jeho rozšírenia v 3. - 4. storočí po začlenenie regiónu k Ruskému impériu v 19. storočí, prešlo svojráznymi metamorfóznymi zmenami a u každého národa regiónu malo svoju vlastnú históriu. Na jednej strane staré zakaukazské kultúry (arménska a gruzínska) si v plnej miere osvojili krestanstvo a naprieč storočiami ho udržali. Horské národy Kaukazu, ktoré postrádali vlastnú štátnost', osvojili si krestanstvo zväčša len čiastkovo, dlhodobo sa tu prejavoval aj religiózny synkretizmus (zmiešanie pohanstva, judaizmu, krestanstva, islamu) a napokon sa väčšinou islamizovali. Popri množstve vnútorných a vonkajších vplyvov a faktorov, dôležitým sa v týchto procesoch javí aj mentálny konzervativizmus kaukazských etník.

Klúčové slová: pohanstvo, judaizmus, krestanstvo, synkretizmus, islam, kaukazské národy, muchadžirstvo, Ruské impérium

Kaukaz je vo svojej komplexnosti historicky unikátnym regiónom. Má mnohonárodnostný, nábožensky rôznorodý a multikultúrny charakter. Takéto prívlastky nadobudol v dôsledku svojrázneho špecifického historického vývoja. Na Kaukaze sa od pradávna stretávali civilizácie a bol aj akousi 
„etnickou šachovnicou“ národov, ktoré - popri svojej kultúre - boli nositelmi aj vlastných osobitých vierovyznaní a tie prejavom duchovnej kultúry ludí. Pritom dejiny jednotlivých náboženstiev na Kaukaze sú velmi interesantné a ich koexistencia pritahuje pozornost’ vedeckého záujmu. V našom prípade pôjde o komparatívno-historickú štúdiu, ktorá sa pokúsi zmapovat nie až tak genézu krestanstva na Kaukaze, ako skôr jeho metamorfózne prejavy v kontexte celkovej religiozity a dialógu civilizácií v tomto regióne, ktorý má oprávnene aj d’alší prívlastok - križovatka kultúr.

$$
* * * * *
$$

V 1. storočí po Kr., ked'sa podla tradície apoštoli rozišli do rôznych kútov sveta s blahozvestou, Kaukaz bol arénou rivality medzi Rímom a Partskou ríšou. Samozrejme, vplyv impérií sa rozšíril hlavne na Zakaukazsko, ale aj krajiny na sever od centrálneho kaukazského chrbta nezostali bokom od udalostí svetových dejín. Podla legendy, apoštoli Ondrej (vo východnej cirkvi Andrej Prvopovolaný) a Šimon (nazývaný aj Kanaánsky alebo Horlivec) prichádzali na Kaukaz zo strany Čierneho mora a apoštol Bartolomej od Kaspického mora. Napokon existuje aj legenda, že Bartolomej podlahol mučeníckej smrti v okolí mesta Derbent v dnešnom Dagestane (Gumanov 2011). Hoci niesli vieru všetkým národom, smerovali však najprv do židovských komunít Kaukazu.

Celý rad výskumov poukazuje na to, že existencia prvých kaukazských včasnokrestanských komunít bola spojená s prítomnostou židovského elementu na Kaukaze. Z tohto dôvodu je potrebné poukázat na samotnú históriu kaukazských židov, ktorá siaha do hlibky dávnych čias a stráca sa $\mathrm{v}$ hmle literárnych a ústnych tradícií.

Ako svedčia cestopisy z 18. a 19. storočia, medzi kaukazskými židmi ešte žila legenda, že sú potomkami zajatcov, ktorých Asýrčania odviedli zo Samárie (hlavného mesta severného, t. j. Izraelského královstva) a násilne premiestnili do hôr Médie, ktoré sa spájali s Kaukazom. Paralelne s touto legendou, ktorá spája začiatok židovského osídlenia na Kaukaze s dobou zničenia Samaritánskeho královstva (696 pred Kr.), sa zachovala d’alšia legenda, podla ktorej sa začiatok židovského osídlenia na Kaukaze uskutočnil v dobe zničenia Prvého chrámu v roku 587 pred Kr. (Gorskie evrei 1999, 29-30; Istoriya evreev na Kavkaze).

Podla „Dejín Gruzínska“ cároviča Vachuštiho Bagrationa (1745) po zničení Jeruzalema novobabylonským králom Nebukadnesarom II. na konci 6. storočia prišla čast židovských vyhnancov do Iverie (Gruzínska) ${ }^{1}$, kde požiadala správcu mesta Mcchety ${ }^{2}$, aby im poskytol miesto na usadenie sa. Král súhlasil a určil miesto na rieke Zanav, ktoré bolo - vzhl’adom na Židmi platenú daň - nazvané Kerk (daň). Podla inej verzie už spomínaných „Dejín Gruzínska“ sa začiatok židovského osídlenia v regióne datuje do obdobia Druhého chrámu, približne v čase vzniku židovskej diaspóry na Kryme, ked’ sa po jeho zničení (v roku 70 po Kr.) časť židovských utečencov usadila $\mathrm{v}$ Mcchete spolu s ich súvercami, ktorí prišli predtým (Istoriya evreev na Kavkaze; Ioseliani 1843, 5-7). Aj d’alšie písomné pramene potvrdzujú prítomnoste židovskej diaspóry v Mcchete na samom konci 1. storočia pred Kristom (Alekseev 2006, 1-2).

Nie je vylúčené, že prvými adeptmi krestanstva na Kaukaze skutočne boli Židia-Semiti (Hebreji), ktorí sa kedysi ocitli v regióne ako obchodníci, kupci, úžerníci alebo misionári-rabíni. Gruzínske pramene zretel'ne dokumentujú prítomnost̉ mcchetskej židovskej komunity na konci 1. storočia pred Kr. a v prvých storočiach po Kr. (Eliashvili 1926, 39). Podla nich prvými šíritelmi krestanstva v Gruzínsku začiatkom 4. storočia boli Židia Evjatar (Abiatar) z Urbnisi a jeho sestra Sidónia, ktorých Gruzínska pravoslávna cirkev zarad’uje medzi svätých, a taktiež Židovka

1 Vlastné pomenovanie Židov v starohebrejskom jazyku (a tiež aj v súčasnom ivrite - novohebrejčine) je „Ivri“, „Ivrim“. Existuje starožidovské slovo „ivrejon“, ktoré znamená miesto osídlené Židmi. Od tohto pochádzajú údajne aj názvy Iveria - niekedy aj Iberia (Gruzínsko) a Iberia (Španielsko), resp. Iberský polostrov (Pyrenejský polostrov), od dávnych čias osídlené Židmi - presídlencami z Palestíny.

2 Starobylé hlavné mesto východogruzínskeho štátu Kartli. 
Solomea - autorka životopisu sv. Niny Kappadokijskej, ktorá pokrstila Gruzínsko. Vcelku tak židia boli prvými rozširovatelmi krestanstva v Gruzínsku a na Kaukaze.

V tejto súvislosti osobitný záujem púta aj teória objavenia sa na Kaukaze prvých spoločenstiev tzv. horských židov, ktorí vyznávali judaizmus a ktorí (z etnokultúrneho hladiska) absorbovali elementy kultúry kaukazských národov. Tieto špecifiká dodnes odlišujú „horských židov“ od iných židovských skupín. V historickej literatúre existuje niekol'ko verzií a hypotéz pôvodu horských židov. Podla jednej z nich, prvá židovská komunita v regióne bola založená v 6. storočí prišelcami z juhozápadných oblastí sásánovského Iránu. Verzia sa zakladá na neexistencii semitských koreňov u horských židov a postulovaní ich etnogenetických spojení s iránskymi Tatmi, ktorí prijali judaizmus a boli presídlení na Kaukaz sásánovským králom Husravom I. Anóšarvánom (531 - 579). Druhá verzia vedie k tomu, že predkami horských židov boli akoby Peržania, ktorí po svojom presídlení na Kaukaz prijali judaizmus pod vplyvom Chazarov. Základom pre vznik a vývoj tejto verzie zrejme bola príbuznosṫ medzi tatskými a horskožidovskými jazykmi (Farzaliev 2008, 170-171).

Čo sa týka Chazarov a prítomnosti židovského prvku na Kaukaze - ten sa medzi iným prejavoval unikátnym konfesionálnym javom, obdoba ktorého sa nenachádza v dejinách. Je pravdou, že sa to stalo o niečo neskôr - niekol'ko storočí po Kr. Na pomedzí východnej Európy a Ázie zo severu priliehalo ku Kaukazu silné Chazarské královstvo (650 - 969) (Golden 2007, 7), ktoré vzniklo na troskách Vel'kobulharskej ríše (tzv. Onogurie) a na začiatku centrum tejto štátnosti sa nachádzalo v prímorskej časti dnešného Dagestanu. Chazari (v prameňoch aj Kovari) boli zrejme turkickým etnikom (nejasného pôvodu), teda boli úplne cudzí Židom, ale napriek tomu istá čast poddaných chazarského kagana prijala judaizmus (pritom v Chazarskom kaganáte vyznávali aj krestanstvo a islam i šamanizmus - pozn. autora). Chazari boli teda jediným nehebrejským etnikom, ktoré kolektívne prijalo judaizmus. „O to viac je to interesantné, že duch proselytizmu bol vždy cudzí Židom. Oni sa pokladali za Bohom vyvolaný národ, nielen ako veriaci v skutočného Boha, ale aj ako deti Abrahámove. Neverou mohli stratit túto vysokú výhodu, ale cudzinci ju vierou nenadobúdali. Obrátenie Chazarov v judaizmus svedčí o tom, ako niekedy tento element, hoci aj pasívne, bol silným v krajinách, kde je teraz ledva viditelná jeho prítomnost" (P.U. 1869, 7). Berúc do úvahy časté pochody Chazarov do Zakaukazska, ich vládu nad Dagestanom a existenciu chazarských miest na východnom Kaukaze existuje domnienka, že prijatie židovskej viery elitou kaganátu sa uskutočnilo hlavne pod vplyvom jemu podriadených kaukazských židov (Istoriya evreev na Kavkaze).

Medzitým sa krestanstvo postupne zakoreňovalo v Arménsku, Gruzínsku a v kaukazskej Albánii. Vo 4. storočí pred Kr. sa objavujú aj prvé napoly legendárne informácie o krestanských kláštoroch v historickej Alanii (t. j. kaukazskej Alanii).

V Arménsku sa krestanstvo začalo šírit v 2. - 3. storočí, hoci vznik krestanskej cirkvi sa tu traduje do doby pôsobenia apoštolov Tadeáša a Bartolomeja. Aj ked’ do Arménska (historického Arménska - územne sa rozprestierajúceho medzi Kaspickým, Čiernym a Stredozemným morom) už v 2. storočí po Kr. prišli grécki misionári z Cézarey, za apoštola je však považovaný až sv. Gregor Iluminátor (tiež Grigor Lusavorič, †328), ktorý prijal krst v Cézarei Kappadóckej. Práve on priviedol ku krestanstvu arménskeho krála Tiridata III. (Tiridates, tiež Trdat; 287 - 330). Ten následne vyhlásil krestanstvo za štátne náboženstvo. Stalo sa tak v roku 301, t. j. osem desatročí predtým, než tak roku 380 po Kr. učinil cisár Theodosius Velký v Rímskej ríši. Gregor Iluminátor sa súčasne stal prvým biskupom vo Vagharšapate (Szabo 2016, 29-30) a začal používat titul katolikos ${ }^{3}$. Následne, na začiatku 4. storočia krestanstvo prijal aj gruzínsky panovník Mirián III. (265 - 342)

3 Katolikos - pôvodne zástupca antiochijského patriarchu, neskoršie hlava nezávislých (najmä východných) cirkví (dodnes arménskej cirkvi). 
(Otechestvennaya istoriya 1994, 105, 642). Novovzniknutá gruzínska cirkev bola do polovice 11. storočia podriadená antiochijskému patriarchovi (Aleš 1978, 175-176) a jej predstavitel' bol prítomný (spolu s arménskymi delegátmi) už na prvom Nicejskom koncile v roku 325.

Gruzínske obrátenie na krestanstvo sa pripisuje pôsobeniu rodáčky z Jeruzalema - už spomínanej Niny Kappadokijskej, ktorú Gruzínci pomenovávajú Nino (je apoštolkou a patrónkou Gruzínska - pozn. autora), Arméni - Nune a u gréckych spisovatelov sa objavuje ako Nonna, čo v latinčine znamená mníška. V Jeruzaleme kolovala legenda, že chitón Pána je ukrytý v Mcchete a sv. Nina sa zapálila túžbou vidiet túto svätyňu a hlásat Božie slovo v kaukazskej Ivérii (gruzínskom Kartli) (P.U. 1869, 14-15). Vo Vakuštijanových „Dejinách Gruzínska“ sa uvádza krestanská legenda, podla ktorej sv. Nina (314 po Kr.) pricestovala do Urbnisi a vošla do štvrti obývanej židmi, s ktorými sa mohla slobodne rozprávat. V čase svojho prebývania v Mcchete sv. Nina často navštevovala židovské mesto a podarilo sa jej obrátit’ na krestanstvo židovského rabína Evjatara, ktorému je pripisovaná dôležitá úloha v christianizácii Gruzínska (Istoriya evreev na Kavkaze).

Napokon aj kaukazská Albánia ${ }^{4}$ patrí do radu tých krajín, kde prvé krestanské komunity vznikli ešte dávno pred 4. storočím - pred ustanovením krestanstva štátnym náboženstvom. Podla albánskej tradície začiatkom prvých storočí po Kr. do Albánie prenikali prví krestanskí misionári, apoštoli (Bartolomej a Júda Tadeáš) a ich žiaci a stúpenci z Jeruzalema, zo Sýrie a zakladali prvé krestanské komunity. V prvom rade tomu bola nápomocná existencia starožidovských osídlení dávno pred 1. storočím po Kr. a v 1. storočí po Kr. aj nazarénov - židovských krestanov, resp. židokrestanov z Palestíny (Geyushev 1984, 134). Uznanie a oficiálne prijatie krestanstva v kaukazskej Albánii prebiehalo fakticky synchrónne s Rímskou ríšou. Albánsky panovník prijal krestanstvo v roku 314 (po vydaní Milánskeho ediktu v roku 313) a štátnym náboženstvom stalo sa krestanstvo v albánskom štáte v roku 326 (po Nicejskom koncile v roku 325). (Alyshov 2018, 228).

Napriek prijatiu krestanstva arménskymi a gruzínskymi panovníkmi sa však pohanstva ich poddaní zbavovali tažko. Ako poznamenáva historik Zenobius, krestanská žiarlivost̉ novoobrátených arménskych kniežat viedla $\mathrm{k}$ drsnému a krvavému prenasledovaniu modloslužobníkov. V Gruzínsku ešte aj po 200 rokoch od prijatia krestanstva králom Miriánom existovali pohanské oltáre na hore Zaden v okolí panovníckeho hlavného mesta. Miestne prostriedky na šírenie krestanstva zjavne nestačili a okolo roku 550 - s požehnaním slávneho pustovníka Šimona Stylitu do Gruzínska došla misia kazatelov, známych v gruzínskych cirkevných dejinách ako 13 sýrskych otcov. Títo sú považovaní za zakladatelov najznámejších kláštorov a kostolov v krajine a uctievaní za svätých, ktorí dokončili dielo začaté mcchetskými židmi a sv. Ninou (P.U. 1869, 15).

Analyzujúc útržkovité informácie o šírení krest’anstva na Kaukaze gruzínskymi, arménskymi a agvanskými kazatel’mi je možné vyvodit záver, že semeno krestanskej viery tu nikdy nedozrelo do požehnanej žatvy: výhonky boli zničené nezhodami. Dôvody nie je tažké vysvetlit. Napríklad Dagestan je oddelený od Gruzínska a od rovinatej časti Agvanie (kaukazskej Albánie) tažko prekonávanými prírodnými rozhraniami. Preto sa vplyv gruzínskych, arménskych alebo agvanských panovníkov nikdy pevne neujal v horách Centrálneho Kaukazu. Niekedy isté skupiny horalov, sledujúc pritom rôzne motívy, uznávali moc toho či iného suveréna, ale takáto poddajnost̉ bola

4 Kaukazská Albánia - staroveký polyetnický štátny útvar, ktorý vznikol na konci 2. - v polovici 1. storočia pred Kr. vo východnom Zakaukazsku (východne od starovekého Arménska v horách dnešného Azerbajdžanu). Jeho obyvatel'stvo hovorilo jazykmi lezginskej vetvy nachsko-dagestanskej jazykovej rodiny a bolo konglomerátom 26 kmeňov, v ktorom vedúcu úlohu zohrával kmeň Albáncov (tiež Agvanci, resp. Aghvanci); podla neho je nazvaný aj celý zväz. V polovici 5. storočia po Kr. kaukazská Albánia stratila nezávislost’ a stala sa súčastou sásánovského štátu. Názov Albánia (Albánsko) je starogrécky a označuje horskú krajinu. Neskôr dostalo toto územie perzské pomenovanie Aran (Arran) a následne jej južné regióny získali turkicko-iránske pomenovanie Karabach. 
úplne imaginárna. Horali lahko vyjadrovali pokoru, pretože ju nepovažovali za povinnú alebo akokolvek obmedzujúcu ich nezávislost'. V zásade lahko prijímali krestanskú vieru a podobne lahko sa jej aj zriekali (P.U. 1869, 15).

Dôležitým medzníkom v dejinách krestanstva na severnom Kaukaze boli misie byzantského cisára Justiniána v polovici 6. storočia na čiernomorské pobrežie Kaukazu - do prostredia abcházsko-adygských etník. Podla V. B. Pfafa, doktora práv a člena Kaukazského oddelenia Ruskej geografickej spoločnosti, išlo o významnú udalost' v christianizácii východného čiernomorského pobrežia a Čerkeska, resp. Čerkesov. ${ }^{5}$ V roku 562 Justinián uzavrel mier s Peržanmi a Lazika ${ }^{6}$ bola vrátená Byzancii. Mier s Peržanmi umožnil obrátit’ pozornost’ cisára na horské národy Kaukazu. Po jednej z expedícií do Alanie $e^{7}$ pravdepodobne prevzal Justinián do svojho mena aj prímenie Alanicus. Podriadili sa mu všetky horské kmene od rieky Terek po Tamanský polostrov. Najviac sa pod byzantský vplyv dostali Abcházci a Čerkesi, ktorí v tom čase žili v horách západnej časti Kaukazu a okolo ústia rieky Kubáň. Odvtedy sa krestanstvo medzi horalmi rozširovalo s velkým úspechom, a preto v príbehoch rôznych kaukazských národov, ked’ sa hovorí o „hore Čerkeskej“, sa zvyčajne pridáva prívlastok „krajina krestanov“. Na celom západnom Kaukaze v tom čase kázali grécki misionári. Existuje verzia, že Justinián založil biskupstvo v meste Nikopsis na hore Kasburun na Tamanskom polostrove, v blízkosti súčasného Nalčika - teda v krajine Alanov (Pfaff 1871, 7-8).

5 Podla Encyklopedického slovníka Brockhausa-Efrona (vydávaného v Ruskom impériu v rokoch 1890 1907) pod názvom Čerkesi je označovaná skupina kmeňovo rôznorodých, avšak jazykom a kultúrou príbuzných západno-horských národov Kaukazu, obývajúcich (až do svojho vystahovania po ovládnutí Ruskom) väčšiu časț Kabardinskej plošiny, značnú čast oboch kaukazských hrebeňov a východné pobrežie Čierneho mora. Čerkesi sa rozdelujú na tri velké skupiny: na vlastných Čerkesov alebo Adygejcov (resp. Adyge ako sa sami nazývajú), Kabardov a Abcházcov. Do prvej velkej skupiny (Čerkesi - Adyge) patria nasledujúce etniká: Abadzechovia, Šepsugovia, Natuchajci, Beslenejevci, Jegarukajovia a Mecheševci, Gatiukajevci, Temirgojovci (Kemgujovci), Bžeduchovia a nakoniec Žanejevci i velmi zmiešaný kmeň Ubychov. Čerkesi žili na Kaukaze takmer na rovnakom teritóriu od staroveku. Etnonym Čerkesi im bol daný okolitými etnikami (zrejme pochádza z turkických slov čer - cesta; kesmek - odrezat', t. j. Čerkes ako synonymum zbojníka), sami seba ale vždy nazývali Adyge. Už u gréckych historikov sa nachádza pomenovanie Kerket, ktoré sa vztahuje práve na Čerkesov. Gréci ich nazývali aj Zichmi. V minulosti územie Čerkesov, okrem západného Kaukazu, sa rozprestieralo aj na Krymský polostrov. Ešte v roku 1502 ovládali východné pobrežie Azovského mora až do Bosporu Kimmerijského (starogrécky názov dnešného Kerčského prielivu - pozn. autora), odkial' boli vytesnení Tatármi a Rusmi. Z Byzancie prevzali krestanstvo a spolu so všeobecnými podmienkami historického života Kaukazu - tejto otvorenej cesty národov - vytvorili si sociálny ústroj militantného feudalizmu, ktorý sa tu zachoval neporušený až do éry boja s Ruským impériom. Čerkeská odvaha, čestnost', prísne mravy, vel'korysost', pohostinnost’ boli rovnako preslávené ako krása a pôvab ich mužov a žien. V spôsobe života boli prostí a prirodzení. Sám ich život bol však plný drsnosti, krviprelievania a krutosti (Encyklopedicheskiy slovar 1903, 580-582).

6 Lazika (Egrisi) - staroveký štátny útvar (královstvo) v juhovýchodnom Pričiernomorí (na území dnešného západného Gruzínska a Abcházska). Vznikla v 1. storočí po Kr. kmeňovým zjednotením Lazova podmanením Kolchidského královstva, resp. bola jeho nástupnickým štátom. Začiatkom 4. storočia bola v Lazike zriadená prvá krestanská eparchia a v roku 319 krestanstvo sa stalo štátnym náboženstvom. V 6. storočí bola objektom zápasu medzi Byzanciou a Perziou. Zanikla v 8. storočí pripojením územia k Abcházskemu královstvu.

7 Alania, resp. Alanské královstvo - stredoveký štátny útvar Alanov (iránskojazyčných kočových kmeňov skýtsko-sarmatského pôvodu) založený v predhorí severného Kaukazu v 8. alebo 9. storočí. Alania ako samostatný štát prestala existovat po mongolskej invázii $(1238$ - 1239). Posledným úderom pre Alanov boli vpády Tamerlána v rokoch 1395 a 1400. Preživší Alani, ktorí sa ukryli v horách Centrálneho Kaukazu a Zakaukazska, po zmiešaní s miestnymi autochtónnymi kmeňmi vytvorili etnikum Osetov. Ludoprázdne predkaukazské územia Alanie boli obsadené Čerkesmi - vznikla tu politická jednotka nazývaná Kabarda a začal sa formovat kabardinský subetnos. 
Zrejme v tom čase siet’ krestanských eparchií podriadených Konštantínopolu obsiahla teritórium od pobrežia Čierneho mora do severnej Alanie. Napokon v Alanii mohli byt Justiniánovi misionári úspešní - konštatuje V. B. Pfaf - pretože Alani k celoplošnému prijatiu krestanstva boli istým spôsobom pripravení už v 1. storočí. Avšak vzhladom na ich vtedajšiu divokost' nie je možné hovorit’ o pravom krestanstve, skôr o oboznámení sa s rituálmi včasnostredovekého krestanstva (Pfaff, 1871: 8).

V 6. storočí počas dlhotrvajúcich vojen Justiniána I. s perzským šachom Husravom I., ktoré sčasti prebiehali na území Gruzínska, bola táto krajina už celkom krestanská. Historik týchto vojen Prokopius z Cézarey svedčil o predkoch Gruzíncov: „Iberiáni sú krestania a lepšie od všetkých nám známych národov dodržiavajú obrady krestanskej viery“ (Tsagareli 1891, 3-4). V období mono- a dyofyzitských sporov sa arménsky katolikos nezúčastnil Chalcedónskeho koncilu (451), $\mathrm{v}$ obave z upadnutia do herézy nestorianizmu odmietli Arméni spolu s gruzínskou a albánskou cirkvou jeho christologické závery na svojom vlastnom sneme v Dvine roku 506. V tej dobe už boli sami silno prenasledovaní novoperzskými Sásánovcami, ktorí ich nútili prijat zoroastrickú vieru mazdaznan (Szabo 2016, 30).

V 7. storočí pod údermi zoroastrickej Perzie musela Byzancia odstúpit z Kaukazu. Ničivá vojna medzi cisárom Herakleiom (610 - 641) a šachom Husravom II. Pervezom (590 - 628) spustošila územie od Čierneho mora po Perzský záliv a následne na ludoprázdnych teritóriách zavládla tretia sila - moslimskí Arabi. V tomto období sa severokaukazské eparchie dočasne podriadili patriarchovi Gruzínska. Vplyv Byzancie sa však opätovne posilnil v 10. storočí. Medzitým v rokoch 860 861 do Chazarského kaganátu smerovala druhá misia (v službách byzantského cisára Michala III.) sv. Konštantína (Cyrila) a Metoda (Ivanič - Lukáčová 2014, 4-7). Na ceste do Chazarského kaganátu solúnski bratia navštívili Severný Kaukaz. Traduje sa, že ich misia zintenzívnila hnutie v prospech šírenia krestanstva. Takzvané „velké krstenie Alanov“ sa datuje rokom 916 (pritom krstenie Kyjevskej Rusi až v roku 988). Obracat Čerkesov na krestanstvo začali na konci 10 . storočia kyjevskoruské kniežatá z Tmutarakaňa (na Tamanskom polostrove) a misie gruzínskych králov. Christianizácii regiónu významne napomohla aj činnost̉ Byzancie. V 10. - 11. storočí tak väčšina národov severného Kaukazu - od Adygov na západe po Dagestancov na východe - bola pokrstená. Alanská metropolia, formálne podriadená Konštantínopolu (vznikla v 10. storočí), tak spravovala krestanské územia a národy od Čierneho po Kaspické more. Jej centrum sa podla archeologických nálezov nachádzalo v doline rieky Zelenčuk (v dnešnom Karačejevsko-Čerkesku) (Gumanov 2011). Avšak súčasne z juhu začína prienik islamu, turkickí moslimovia postupne osídlovali územie dnešného Azerbajdžanu.

Alanské královstvo bolo zničené mongolskými hordami v 13. storočí. V 14. storočí sa po predhoriach Kaukazu prehnali vojska Tamerlána. Civilizácia kaukazského predhoria sa dostala do úpadku. Z viacerých predtým „rozkvitnutých“ miest neostali ani ruiny. Alani (predkovia Osetov) a Adygovia (predkovia Čerkesov, Kabardov a Abcházcov) odišli z rovín do hôr, čast’ Alanov sa presídlila do Zakaukazska. Do predhoria vstúpila taktiež čast' kumánskych kočujúcich kmeňov - budúcich Karačajevcov a Balkarov. Najviac bol zasiahnutý Dagestan, kedže cez Dagestanskú bránu dlhodobo prechádzali hordy kočovníkov. Tam krestanstvo ustupuje islamu už v 14. - 15. storočí (Gumanov 2011). Napokon dobytie Konštantínopola v roku 1453 osmanskými Turkami bolo udalostou najvyššej dôležitosti všeobecne pre všetkých východných krestanov, ktorí videli v Byzancii prirodzenú podporu a patrónku krestanskej cirkvi a krestanských národov Východu.

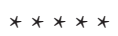

Podobne zložito sa vyvíjala situácia v regióne južného Kaukazu - v Zakaukazsku. V obave o národnú a náboženskú čistotu arménska cirkev neudržiavala communio nielen s Rímom, ale od roku 1015 - ked' Byzancia obsadila čast’ pôvodnej vlasti Arménov - ani s Konštantínopolom. Staroveké 
arménske královstvo bolo v 11. storočí rozvrátené Seldžukmi, následne skazu krajiny dovŕšil v 13. storočí vpád Mongolov a v 14. storočí pochody Tochtamiša a Tamerlána. Od epochy seldžuckých výbojov sa spustil mnohostoročný proces vytesnenia arménskeho obyvatel'stva $\mathrm{z}$ historického územia turkickými kmeňmi. Arménske obyvatelstvo bolo masovo odvliekané do zajatia a utekalo do okolitých krestanských regiónov (Petrushevskiy 1949, 35). Čast’ Arménov utiekla do Kilíkie na juhu Malej Ázie, kde založila nové arménske Kilíkijské královstvo (1080 - 1375) a v meste Sis aj nové sídlo arménskeho katolikosa. Ten po dobytí Sisu moslimskými mamelukmi roku 1375 presídlil spät do Vagharšapatu. Zároveň vznikla schizma, ked’ bol aj v Sise zvolený druhý patriarcha a tento stav pretrvával až do roku 1997 (Szabo 2016, 30). V priebehu 15. storočia stali sa časti arménskeho územia súčastou štátov vytvorených turkickými kočovnými kmeňmi Kara-Kojuunlu a Ak-Kojuunlu. V 17. storočí bolo územie obývané Arménmi rozdelené medzi osmanských Turkov a Perziu. Perzskú čast' začiatkom 19. storočia napokon ovládlo Ruské impérium.

Situáciu okolo oslabenia krestanskej Iverie (Gruzínska) a následne aj pádu Konštantínopola opisuje profesor Sankt-Peterburgskej univerzity A. A. Cagareli. Podla neho arabská nadvláda v 7. - 9. storočí síce oddialila vzostup krestanskej kultúry Gruzínska, avšak s oslabením Arabov a posilnením vplyvu Byzancie v 10. storočí opätovne sa jej rast v krajine - za vlády dynastie Bagrationov - posilnil. Obdobie 10. - 12. storočia v Gruzínsku môže byt skutočne považované za periódu rozmachu politickej a vojenskej moci, rozkvetu literatúry, umenia a verejného života. Tento zlatý vek Gruzínska ukončila napokon invázia Mongolov na začiatku 13. storočia (Tsagareli 1891, 5).

Súpadkom mongolskej mociv Malej Ázii nadobúdajú silu osmanskí Turci. Pád Konštantínopola v polovici 15. storočia bol obzvlášt citlivý pre Gruzínsko, tisícročného spojenca Byzancie, s ktorým ho spájala rovnaká viera, príbuznosṫ vládnucich dynastií, krestanská kultúra, politické a vojenské záujmy. Krátko po obsadení Carihradu sa rímski pápeži snažili pozdvihnút západných a východných krestanov proti Turkom. Pápež Pius II. poslal do Ázie mnícha (pápežského nuncia) Ludovíta Bolonského (Ludovico de Bologna), aby propagoval novú krížovú výpravu proti Turkom za oslobodenie Konštantínopola a Svätej zeme. V apríli 1459 cisár Trapezuntskej ríše Dávid Megas Komnenos písal pápežovi, že on a jeho spojenci - gruzínski králi a vládcovia a tiež niektorí nespokojní moslimskí kniežatá, sú pripravení začat vojnu proti Turkom, aby ich vyhnali zo Svätých miest a Konštantínopola. Spojenci sa už zhromaždili pri mori, ale „francúzsky král“ Filip III. Burgundský sa neodvážil osobne zúčastnit výpravy a, čiastočne aj kvôli tomu, sa taženie zrušilo. Zachovali sa, okrem listu trapezuntského cisára Dávida, aj listy gruzínskeho cára Georgia VIII. a achalcichského ${ }^{8}$ vládcu adresované pápežovi. V listoch písali do Ríma, že proti Turkom sú schopní zhromaždit’ viac ako 100000 vojakov (Vasiliev 1936, 281) a pokial Latinci súčasne zaútočia na Turkov z Grécka, potom bude možné za jedno leto vítazne ukončit výpravu: vyhnat' Turkov a dobyt' Antiochiu, Bursu a Konštantínopol (Tsagareli 1891, 5). Napokon stalo sa niečo iné. Tri roky po tejto predpokladanej expedícii Trapezunt postihol osud Konštantínopola - bol dobytý Turkami v roku 1461.

V 13. - 14. storočí - ešte pred vládou Turkov - dominovali v Prednej Ázii egyptskí mamelukovia a Mongoli, ktorí viedli medzi sebou dlhotrvajúce krvavé vojny kvôli ovládaniu Sýrie a Palestíny. Podla A. A. Cagareliho - krestania sa v tomto čase nemohli zvlášt stažovat na velký nátlak z ich strany; naopak, v snahe získat na svoju stranu krestanské obyvatel'stvo tohto regiónu súperi im poskytovali určité privilégiá v mieste ich pobytu a vo Svätej zemi. Najmä Mongoli, ktorí pred prijatím islamu zaobchádzali s vel'kou toleranciou voči krestanskej cirkvi a krestanom. Ale zhruba po 60 rokoch od pádu Konštantínopola, ked’ Turci v rokoch 1516 - 1517 dobyli Sýriu, Palestínu, Egypt a stali sa tak jedinými a zvrchovanými vládcami všetkých krajín od Kaukazu až po brehy Nílu, sa

8 Achalciche - gruzínske mesto, centrum historického regiónu Samcche-Džavacheti. 
postavenie krestanov skomplikovalo. Práva krestanských bratstiev boli obmedzené, bola uložená špeciálna daň na kostoly a kláštory. Ak krestanské spoločenstvo nebolo schopné platit daň za svoj kláštor, Turci ho okamžite odobrali a dali ho tej komunite, ktorá im ponúkala platit za kláštor viac a pravidelne. Práve týmto spôsobom v roku 1559 františkáni dostali od Turkov za velký poplatok najstarší gruzínsky kláštor sv. Jána Bohoslovca a premenovali ho na kláštor Spasitela (St. Salvator) (Tsagareli 1891, 6).

V 15. storočí sa Gruzínske královstvo zmenilo na izolovanú krestanskú krajinu, zo všetkých strán obklopenú moslimským svetom. Väčšina jej susedov prestala existovat po páde Konštantínopola v roku 1453 a rozšírení osmanského vplyvu na celý čiernomorský región. Spojenie Gruzínska s krestanským svetom sa uskutočňovalo najmä prostredníctvom kontaktov s janovskými kolóniami na Kryme. Napokon sa Gruzínsko v roku 1460 rozpadlo na tri královstvá (Kartli, Kachetia a Imeretia) a niekolko kniežactiev. Od konca 15. storočia prebiehali vojny Gruzíncov s Perziou a Osmanmi, ktoré skončili v roku 1555 rozdelením Gruzínska na sféry vplyvu: jeho východná čast’ (Kartli a Kachetia) zostala pod politickým vplyvom Perzie, západná čast' (Imeretia) - pod vplyvom Osmanskej ríše. Okrem toho Turci ovládli južné Gruzínsko s mestom Achalciche, ktoré dominovalo nad Tiflisom (dnes Tbilisi) a východným pobrežím Čierneho mora, a v oblasti vybudovali pevnosti s tureckými posádkami. Zároveň sa Turci pokúšali šírit islam medzi gruzínskym národom, v čom aj čiastočne boli úspešní. Invázie Osmanov do západného Gruzínska (Imeretie) v 16. a 17. storočí boli poznačené devastáciou a krutostou. Svedkom tureckého barbarstva sú zrúcaniny jednej z najvýznamnejších pamiatok cirkevnej architektúry 10. - 11. storočia gruzínsko-byzantského štýlu - slávna katedrála cára Bagratiho v Kutaisi (Tsagareli 1891, 7).

Na podporu Gruzínska patriarchovia pravoslávnych východných cirkví svojimi listami a posolstvami gruzínskym králom a katolikosom, ako aj osobnými návštevami krajiny, poskytovali gruzínskej cirkvi a krestanom vel'kú morálnu podporu. Proti sile však bolo potrebné sa postavit’ silou. Gréci, ktorí sa roztrúsili po tureckom obsadení Konštantínopola do rôznych krajín, prišli vo velkom aj do Gruzínska, najmä po páde Trapezuntu a nepochybne prispeli k zblíženiu medzi Ruskom a Gruzínskom. Gruzínskymi vyslancami do Ruska boli často Gréci a listy samotných gruzínskych králov boli často písané v gréčtine (Tsagareli 1891, 7-8). V roku 1783 panovník spojeného Kartli-Kachetského královstva (1762 - 1801) Heraklius II. a ruská cárovná Katarína II. podpisujú Georgijevský traktát, na základe ktorého sa Gruzínsko stáva ruským protektorátom. Na základe Manifestu cára Pavla I. bolo východné Gruzínsko v roku 1801 anektované a pripojené k Ruskému impériu. Do konca 70. rokov 19. storočia boli k Rusku pripojené aj ostatné častí Gruzínska, často za pomoci vojenskej sily a potlačením niekolkých povstaní.

Čo sa týka regiónu severozápadného Kaukazu - úspechy šírenia krestanstva medzi Čerkesmi-Adygejcami boli zastavené prakticky v 11. storočí. Adygejci sa najprv dostali pod vládu Chazarov, potom Polovcov a nakoniec v 12. storočí mongolsko-tatárskych panovníkov, ktorí v 14. storočí prijali islam „šírený ohňom a mečom“. Pád Byzancie v 15. storočí prispel k vzniku Krymského chanátu a následným pokusom o islamizáciu Kabardov. Odvtedy krestanské chrámy v krajine Čerkesov pustli, ale v pamäti čerkeských etník sa zachovali mnohé príznaky príslušnosti ich predkov ku krestanskej grécko-východnej cirkvi (Cherkasov et al. 2016, 558). Pozastavenie šírenia krestanstva, jeho príčiny a následky významný kaukazológ a lingvista Leonid Jakovlevič Ljulie charakterizoval nasledovne: „S oslabením vplyvu Gruzínska na kaukazské kmene sa krestanská viera, z nedostatku kazatelov, nevyhnutne rozpadla. S pádom Byzancie a vznikom osmanskej nadvlády celé morské pobrežie padlo do tmy nevedomosti a barbarstva" (Lyulie 1990, 26).

Napriek všetkému v Osetsku a čiastočne aj v Kabarde - najrozvinutejších kniežactvách severného Kaukazu - krestanstvo dokázalo prežit „temné obdobie“. Krestanskými zostávali aj mnohé 
adygejské (čerkeské) a čečenské rody. Zachovali sa aj epizodické vztahahy s Gruzínskom a gréckou štátnostou v Trapezunte (Gumanov 2011).

L. J. Ljulie tak vo svojich spisoch poukazuje, že na Severnom Kaukaze vznikol problém, ktorý medzi tamojším krestanstvom bude tliet ešte po dlhé storočia. Ide o to, že krestanská cirkev je vel’mi zranitelná. Tajomstvá, vrátane hlavného z nich - eucharistie, môže vykonávat jedine kňaz. Ten môže byt vysvätený jedine biskupom - a biskup inými biskupmi, ktorí vedú svoje nástupníctvo od Kristových apoštolov. Preto fyzická likvidácia alebo geografické oddelenie biskupstva zanecháva národ bez dušpastierov. Ked’ vpády a vojny zaplavili Kaukaz a pretali dovtedajšie spojenia, krestanstvo tu proste začalo hasnút. Mnohé kmene sa vracali k pohanstvu, v ktorom krestanskí svätí sa podivne miešali zo starými bohmi. Túto situáciu následne využívali katolíci z janovských kolónií Krymu - do severozápadných regiónov Kaukazu prúdili misionári - františkáni. Hoci v konečnom dôsledku boli tieto misie neúspešné, mali však nezanedbatel'ný vplyv na podporu hasnúcej viery (Gumanov 2011; Pravoslavie 2011).

Je evidentné, že jednotlivé krestanské etniká na severozápadnom Kaukaze sa čiastočne doplňovali alebo udržiavali aj v dôsledku imigrácie do oblasti európskych, ako aj zakaukazských krestanov. Takéto konštatovanie sa natíska v súvislosti s otázkou antropologického výzoru pobrežných Ubychov a aj príchodu do Čerkeska tzv. čerkesogajov (11. - 15. storočie).

V roku 1836 anglický cestovatel' Edmund Spenser navštívil Ubyšsko a v prípade ubyšských rolníkov si všimol isté odlišnosti: „čierne vlasy, reliéfny nos, úzka tvár, uši ako u Židov a hlava viac komprimovaná oproti ostatným Čerkesom; rovnako ako v akejkolvek inej charakteristickej črte ich vonkajšieho vzhladu, pripomínajú tie najlepšie typy európskej populácie“(Spenser 2008, 164). ${ }^{9}$ Aj neskorší výskumníci, opisujúc antropologický výzor Ubychov poukázali nato, že sú „vo všeobecnosti podobní s inými kaukazskými horalmi, ale sú charakteristickí vyššou postavou, hrubou stavbou tela a výraznými črtami tváre. Medzi severokaukazskými národmi s podobnými antropologickými špecifikami sa vyznačujú asi len Oseti - národ zmiešaného pôvodu" (Voroshilov 2008, 68). Domnienku o Ubychoch ako o zmiešanom národe vyslovil vo svojej knihe aj ruský spravodajský dôstojník barón F. F. Tornau: „oni (Ubychovia - pozn. autora) pochádzajú z Abazincov, Čerkesov a tiež Európanov vyhodených - ako hovorí legenda - na čerkeskom brehu ešte v období prvej križiackej výpravy" (Tornau 2008, 164). Tá, ako je známe, sa konala v rokoch 1096 - 1099 a zrejme ovplyvnila región, kedže sa vojská schádzali v oblasti Konštantínopola. Ak môžeme verit legende, tak Európania dokázali asimilovat čast' miestnych a vytvorit zmiešanú spoločnost' - ubyšskú.

Prípad príchodu Európanov na čerkeské pobrežie Čierneho mora evidentne nebol jediným z kontaktov križiakov a iných európskych krestanov s miestnymi Adygejcami, bolo ich zrejme viac. Nevel'ké oddiely týchto sa osídlovali medzi kaukazskými domorodcami a brali za ženy Čerkesky. Kaukaz ako križovatka národov má aj v tejto súvislosti svoje opodstatnenie (Cherkasov et al. 2018, 90). Napokon ešte jedna udalost’ - spojená s čerkesogajmi severného Kaukazu (iné označenie: horskí alebo čerkeskí Arméni, Adygo-Arméni alebo zakubáňski Arméni) a históriou vzniku Armaviru - v plnej miere podporujú vyššie uvedenú hypotézu.

9 E. Spenser skúmal istú antropologickú svojráznost’ aj u Abazincov. Nachádzal v nich židovské korene. Ako dôkaz uvádzal manuskripty nájdené v Gruzínsku, Megrelsku (historická oblast’ v západnom Gruzínsku, obývaná Megrelmi) a Arménsku, z ktorých vyplývalo, že niektoré rody žijúce v tom období (v 19. storočí) v Abazii mali pôvod od raných krestanov, židov obrátených na krestanstvo. Pokrstení Židia, prenasledovaní svojimi súkmeňovcami a rímskymi vládcami, utiekli na Kaukaz a tu sa usadili. Svoje tvrdenia E. Spenser odôvodnil osobnými pozorovaniami, poukazujúc na to, že „črty tvárí niekolkých rodov ešte aj dnes nesú na sebe pečat' ich židovského pôvodu a ich náboženstvo je doteraz zmiešaninou judaizmu a krestanstva“ (Spenser 2008, 159). 
Od polovice 11. storočia začala emigrácia Arménov z historického Arménska. Bolo to spôsobené stratou národnej štátnosti po bojoch s Byzanciou a taktiež po invázii seldžuckých Turkov. Ďalšie odchody Arménov z historického územia boli spojené s tatársko-mongolským vpádom a aj s pochodmi Tamerlána. Ich pôvodné územie sa osídlovalo turkickými etnikami. Pod tlakom kočovníkov si Arméni museli - obrazne povedané - vyberat medzi likvidáciou, otroctvom alebo emigráciou do susedných krajín. To spôsobilo masové presídlenie časti Arménov do Kilíkie, Livanu (Libanonu), Sýrie a dalších regiónov, druhá čast' sa presídlovala na sever - do Gruzínska, na severný Kaukaz a do čiernomorských oblastí (11. - 14. storočie).

Prví Arméni sa objavili medzi Čerkesmi neočakávane. Podla F. A. Ščerbinu: „Do hôr priamo $z$ Arménska prišli ludia vojenského i pôsobivého vzhladu. Boli ozbrojení od hlavy po päty, boli „obalení v železe“, nosili brnenie a drôtené košele ... a ich hlavy boli chránené železnými prilbami; aj ked' nemali štíty ani kopije, mali však bojové sekery s dlhými toporiskami. Vonkajší imponujúci výzor prišelcov urobil dobrý dojem na aborigénov čerkeskej krajiny. V prichádzajúcich vojakoch Čerkesi videli ludís ušlachtilou krvou a s ctou a rešpektom vzali ich medzi seba. Neskôr, ked' títo zaujali významné postavenie v horách medzi Čerkesmi a dostali výsady vyššej šlachty, ktoré im umožnili slobodne vyznávat krestanské náboženstvo, vlastnit nevolníkov a otrokov a zapojit’ sa do všetkých druhov činností, od vojenského remesla po hospodársku prácu a obchod - začali sa $k$ nim stahovat rodáci $z$ Krymu a z rôznych oblastí Malej Ázie, ludia prenasledovaní a utláčaní na týchto miestach dominantnými národmi - Turkami a Tatármi kvôli vyznávaniu krestanského náboženstva" (Shcherbina 1916, 2-3).

Ako teda ukazuje F. A. Ščerbina, od momentu pádu multietnických janovských miest-kolónií a podriadenia Krymského chanátu Osmanskej ríše, k prvej vlne arménskych presídlencov sa pridala druhá - nielen vlastných Arménov, ale aj iných krestanov - z Krymu, Konštantínopola, Trapezuntu, Sinopu a iných regiónov. Obrovské dane (z úrody, hospodárskych zvierat, majetku), vel'ká daň z hlavy, početné povinnosti, ale predovšetkým systematické náboženské prenasledovanie a zákaz rodného jazyka prinútili týchto všetkých utekat rôznymi smermi. Práve vtedy (najneskôr do konca 15. storočia) sa časṫ tejto masy presídlencov ocitla na čiernomorskom pobreží severného Kaukazu. Osídlovali sa v malých skupinách medzi polokrestanskými kmeňmi Adygejcov, ktorí tiež trpeli turecko-krymským obklučovaním, bojovali proti nemu, a nad’alej zachovávali krestanské tradície ako dedičstvo svojich predkov. ${ }^{10}$ Navyše potrebovali medzi sebou skúsených remeselníkov, obchodníkov a bojovníkov. (Vinogradov 1995).

Ako svedčí prípad čerkesogajov - Arméni a aj d’alší európski krestania, žijúc niekol'ko storočí v horách medzi domorodými Adygejcami, úplne stratili svoj etnický vzhlad (a naopak ovplyvnili antropologický výzor domorodcov, zrejme ako tomu bolo v prípade Ubychov), prijali od kaukazských kmeňov ich jazyky, zvyky a osobitosti pobytu, avšak zachovali si svoju krestanskú vieru (minimálne dlhodobo; absurdné by bolo tvrdit, že navždy a všetci). Zrejme práve týmto spôsobom vznikla svojrázna etnicko-náboženská klíma v čerkeskom prostredí.

Čerkesi, ako aj iné etniká Kaukazu, ktoré sa ocitli v obklúčení Osmanského impéria, boli pozbavení priameho kontaktu s krestanskými centrami a stratili duchovných, spočiatku pokračovali v zachovaní krestanských tradícií ako dedičstva svojich predkov. Takáto situácia v regióne

10 Od začiatku 18. storočia, ked’ Čerkesi prechádzali na islam, osídlení v ich prostredí čerkesogaji čelili hrozbe straty svojho náboženstva (patrili k Arménskej apoštolskej cirkvi). Na konci roku 1836 sa čerkeskí Arméni obrátili na velitela Kubánskej línie, generálmajora H. Ch. Zassa, so žiadostou „vziat ich pod ruskú ochranu a poskytnút im prostriedky na usadenie sa blízko Rusov“. Tak v roku 1839 vznikla osada, ktorá položila základy neskoršieho mesta Arvamir. V prvé roky sa v osade nachádzalo 120 rodín a v roku 1840 ich počet vzrástol na 400 rodín čerkasogajov a niekol'ko stoviek horalov-nevolníkov (Shcherbina 1916, 174-177). 
pretrvala minimálne do polovice 18. storočia. Čerkesi vtedy vyznávali učenie troch náboženských kníh - Biblie, Dávidových žalmov a Knihy evanjelistov. Avšak čoraz častejšie sa horské národy Kaukazu prinavracali k pôvodnému pohanstvu, resp. dochádzalo k miešaniu sa krestanských a pohanských obradov a tradícií. Napríklad katolícky misionár - mních (dominikánskej rehole) Giovanni da Lucca, cestujúci po Kaukaze v roku 1625, s údivom zistil, že čast' Čerkesov ešte stále vyznáva krestanstvo východného obradu (Kaukaz 2010, 40-44). Ďalší katolícky misionár Emiddio Dortelli d'Ascoli v prvej tretine 17. storočia pozoroval, že sa u Čerkesov zachovali niektoré dobré krestanské zvyky. Napríklad počas utorkov, stried a piatkov nejedli mäso po celý rok. Dodržiavali pôst pred sviatkami svätých apoštolov v júni a „Uspenie presvätej Bohorodičky“ v auguste. Postili sa aj pred Vianocami a taktiež v období Velkého pôstu - všetko podla gréckeho obradu (Kaukaz 2010, 49).

Pomery v horalskom prostredí západného Kaukazu zmenila občianska vojna 80. rokoch 18. storočia, spojená s činnostou šejcha Mansura ${ }^{11}$ a šírením islamu. Šlachta, ktorá vojnu prehrala, bola pozbavená vlády nad ludom. Najdôležitejším výsledkom sa však stalo zavedenie nového systému náboženských pravidiel, ktorý zmenil krestanské rituály. Rozšírili sa učenia štyroch náboženských kníh - Biblie, Dávidových žalmov, Knihy evanjelistov a Koránu. Inými slovami významným a trvalým výsledkom občianskej vojny bol proces islamizácie regiónu (do Čerkeska sa vlial potok osmanských misionárov). Ten následne vyústil do náboženského rozkolu (Čerkasov et al. 2014, 271).

Napriek evidentným zmenám v náboženskom prostredí ešte aj na začiatku 19. storočia pričiernomorskí Čerkesi aj nadalej vykonávali krestanské obrady prepletené pohanstvom. Svedčia o tom záznamy viacerých európskych cestovatelov, ${ }^{12}$ ktorí v tomto období navštívili región a pozorovali kríže a zachované krestanské pamiatky. Napr. britský emisár James Stanislaus Bell, žijúci medzi horalmi v rokoch 1837 - 1839 (hlavne medzi Šapsugmi, Natuchajcami a Ubychmi) vo svojom denníku v roku 1837 opísal jednu z príhod: „Väčšina na svadbe prítomných ludí sa pohla k starovekému krížu. Zložili svoje prikrývky hlavy a bozkávali ho. Hovorili, že doposial' len malý počet obyvatelov sú obrezaní mohamedáni. Som naklonený tomu verit', súdiac podla malého počtu tých, ktorých som videl modlit sa" (k Alahovi - pozn. autora) (Bell 2007, 256-257). Kaukazológ L. J. Ljulie, ktorý žil medzi Čerkesmi a ovládal ich jazyk, napísal v článku zverejnenom v roku 1866: „Aj teraz sú ruiny krestanských cirkví viditelné na mnohých miestach krajiny Čerkesov (Adyge) pozdľz horných častí rieky Kubáň, najmä pozdľ̌ severného svahu od priesmyku cez Hlavný Kaukazský chrbát do Abcházska“"(Lyulie 1990, 26).

Epicentrom šírenia islamu v 17. - 18. storočí bolo opevnené mesto Anapa, ktoré obývalo turecko-osmanské obyvatel'stvo a ktoré obchodovalo s prilahlými územiami Čerkesov a Kubáne. Súčasne s tým v širšom regióne - od Gelendžiku a d’alej do vnútra pobrežného územia Čerkeska v religióznych vztahoch dominovalo krestanstvo. Miestne obyvatelstvo sa tu postilo, slávilo Velkonočné sviatky - Paschu (dokonca aj s kraslicami), Maslenicu ${ }^{13}$ atd'. Vo velkej časti Čerkesov sa zachovala dávna tradícia pit víno, a to bez ohladu na všetky zákazy a predpisy Koránu - konštatoval J. S. Bell (Bell 2007, 390). Čo sa týka praxe dodržiavania Koránu - francúzsky naturalista

11 Šejch Mansur, Ušurma - islamský kazatel', prvý imám (islamský duchovný vodca) severného Kaukazu, vodca národno-osloboditel'ského hnutia horských národov severného Kaukazu v rokoch 1785 - 1791. Mansur si stanovil za svoj hlavný ciel boj proti otroctvu na Kaukaze, feudálom, krvnej pomste a vo všeobecnosti nahradenie horských obyčajov islamským právom šaría. Zomrel v ruskom zajatí v roku 1791.

12 Čerkesi nevytvorili vlastné písmo a hovorili viacerými (príbuznými) jazykmi. Preto väčšina poznatkov o nich pochádza od množstva európskych, ruských, ázijských a iných cestovatelov, ktorí navštívili severný Kaukaz v rôznych obdobiach.

13 Maslenica - východoslovanský tradičný sviatok slávený v priebehu týždňa pred pravoslávnym Velkým pôstom. Vo svojich rituáloch sviatok zachoval prvky slovanskej mytológie. 
Frédéric Dubois de Montpérreux, ktorý cestoval po Kryme a Kaukaze v rokoch 1831 - 1834, poznamenal: „Iba čerkeské kniežatá a šlachta - moslimovia dodržujú mohamedánske obrady, aj to len pre upokojenie svedomia a s plnou l'ahostajnostou, neraz sa vysmievajúc všetkým ceremóniám “ (Montpérreux 2010, 49). Naopak ruský spravodajský dôstojník barón Fedor Fedorovič Tornau, ktorý navštívil abazinský kmeň Medovejevcov uviedol, že v ich krajine len knieža a niektoré šlachtické rody vyznávali islam. Obyčajní ludia inklinovali k pohanstvu. Títo, nemajúc jasne vymedzenú vieru, sa v prípade neštastia modlili k niektorým útesom a posvätným stromom. „K šajtanovi ${ }^{14}$ cítili neprekonatelný detský strach" (Tornau 2008, 156).

Ako uviedla J. P. Alekseeva: „Pre náboženské prostredie toho obdobia (v Čerkesku - pozn. autora) je charakteristický religiózny synkretizmus - zmiešanie vierovyznaní (pohanstva, krestanstva a islamu). Násilná islamizácia sa tažko presadzovala, prijímala ju v tomto období hlavne nobilita. Obyčajni Čerkesi sa aj nad’alej pridržiavali krestanstva, šíreného Byzanciou a Gruzínskom, a svojich starovekých pohanských vyznaní. Napokon - v18. storočí moslimstvo zvítazilo, ale prežitky krestanstva a pohanstva zostali u Čerkesov do 19. storočia“ (Alekseeva 1959, 23). Inými slovami, navzdory aktívnej islamizácii regiónu vel'ká čast’ obyvatel’ov horského Čerkeska na konci 18. - začiatku 19. storočia pokračovala vo vyznávaní krestanstva. Moslimské náboženstvo tu malo skôr deklaratívny charakter a zakoreňovalo sa rovnako zdíhavo ako predtým krestanstvo. Pritom aj proces zachovania čistoty viery mal svoje charakteristické črty. V miestach obchodných stykov s cudzincami sa pozorovala zvýšená náboženská symbióza a do dialógu moslimskej civilizácie s krestanstvom čiastočne vstupovalo aj pohanstvo. K tomu dochádzalo v dôsledku prítomnosti spoločných kaukazských tradícií, ku ktorým patrilo aj dedičstvo ich predkov. Krestanstvo a pohanské prvky boli vierou dedov - v širšom slova zmysle, a islam stával sa vynúteným opatrením, šíriacim sa militantným spôsobom a zvonku (Šmigel’ et al. 2017, 41).

Zložitou v tomto období bola aj situácia kaukazských židov. Od pádu Chazarského kaganátu a v čase šírenia islamu na severozápadnom Kaukaze podmienky ich života boli mimoriadne tažké. Na konci 18. - v začiatkoch 19. storočia sa v dôsledku objavenia ruských vojsk na Kaukaze ich situácia ešte zhoršila. Obrodený patriotizmus a fanatizmus moslimov viedol k zúrivému prenasledovaniu horských židov: od nich požadovali bezpodmienečné prijatie islamu a aktívnu účast’ v boji s Rusmi. Pogromy a drancovania židovských osád organizovali Kazi-Mulla ${ }^{15}$ a Šamil ${ }^{16}$. Čast’ židov síce zachovala svoju vieru, ale viaceré židovské osady prijali islam. Od nich odvodzujú svoj pôvod dnešní moslimskí Tati, ktorí sa vo vzhlade, jazyku a spôsobe života vel’mi nelíšia od horských židov. Napokon ani po ovládnutí Kaukazu Rusmi sa situácia horských židov nezmenila k lepšiemu (Istoriya evreev na Kavkaze).

Prvé stabilnejšie kontakty národov severného Kaukazu s Moskovským cárstvom sa ustanovujú začiatkom 16. storočia. V roku 1561 sa ruský cár Ivan IV. Hrozný (1533 - 1584) oženil s kabardinskou kňažnou Máriou-Kučenejou (Máriou Kabardinskou) - bola pohankou a krst prijala až v Moskve. V tomto období okrem Kabardy sa nadväzovali vzt’ahy so severozápadnými Adygejcami (Natuchajcami), Abazincami atd'. Následne v období vládnutia Borisa Godunova (1598 - 1605)

${ }_{14}$ Šajtan - v arabskom bohosloví predstavitel kategórie zlých duchov, nepriatel’ských k Alahovi a ludom. Schopný prijat ludskú podobu.

15 Kazi-Mulla (tiež Gazi-Muhammed) - imám Dagastanu, moslimský vedec a kazatel, duchovný líder a vodca národov severného Kaukazu v boji proti Ruskému impériu v období Kaukazskej vojny (1817 1864). Zahynul v roku 1832.

16 Šamil - vodca národno-osloboditel’skej vojny národov Severného Kaukazu v období rusko-kaukazskej vojny (1817 - 1864). V roku 1834 bol vyhlásený za imáma, spojil západný Dagestan a Čečensko, neskôr (v 40. rokoch) aj Čerkesko v teokratický islamský štát Severokaukazský imamát. Je považovaný za jedného z najvýznamnejších vodcov a velitelov v dejinách. Pôvodom bol Avar (jedna z národností Dagestanu). V roku 1859 padol do ruského zajatia. Zomrel v Medine v roku 1871. 
bola založená Astrachaňská eparchia (1602), do územnej pôsobnosti ktorej patrili aj územia k Rusku priatelských národov Kaukazu (Gumanov 2011). Ďalší prienik Rusov bol na dlhší čas zastavený vojnami s Krymským chanátom a Osmanskou ríšou na juhozápade a s Perziou na juhovýchode. Šírenie vplyvu ruskej pravoslávnej cirkvi do regiónu nedokázalo konkurovat intenzívnej islamizácii severného Kaukazu, ktorá prebiehala od 17. storočia.

Ruská politika na severnom Kaukaze sa zaktivizovala začiatkom 18. storočia, ked' v období „Petrových reforiem“ bola Osmanská ríša uznaná za dôležitého historického protivníka, a tak sa stal zrejmým strategický význam Kaukazu. V 30. - 40. rokoch 18. storočia sa na Kaukaze zintenzívnila vojenská prítomnost’ a politický vplyv Perzie. Turecko, ktoré utrpelo porážku vo vojne s ňou v roku 1733, sa dočasne vzdalo nárokov na Dagestan. Perzia opät dobyla Zakaukazsko a kaspické pobrežie. Na druhej strane rusko-turecká vojna (1735 - 1739) bola pre Rusko nepriaznivá a Belehradská mierová zmluva uznala sultána za patróna Čerkeska a vynútila neutralitu Kabardy. Vzhladom na nemožnost' spravovania Kabardy a Osetska, prijíma v roku 1744 Synoda Ruskej pravoslávnej cirkvi riešenie o dočasnom odovzdaní týchto území pod jurisdikciu Gruzínskej cirkvi. V roku 1759 dochádza k migrácii krestanských Kabardov na severovýchod - prijímajú ruské poddanstvo a zakladajú mesto Mozdok (dnes v Severnom Osetsku). Až d’alšia Rusko-turecká vojna (1768 - 1774) a z nej plynúca mierová dohoda ${ }^{17}$ napokon začlenili celé Osetsko a Kabardu do Ruského impéria (Gumanov 2011).

Po ruskej anexii Krymu a pripojení časti Zakubáňska v roku 1783 Turecko, bažiace po revanši, stavilo na strategickú islamizáciu čerkeských národov a podnecovalo nenávist’ voči ruskej prítomnosti v regióne. Čerkesi boli nebezpečnými pre svoje nečakané útoky (v malých skupinách do 50 ludí) na ruské pozície, ktoré sa vytvárali na línii rieky Kubáň. V noci prebrodili rieku a prenikali hlboko do ruského vnútrozemia, rabovali kozácko-ruské obyvatel'stvo, brali zajatcov a dobytok. Pod vplyvom moslimskej propagandy o hroziacom nebezpečenstve zo severu - zo strany Rusov, Čerkesi sa zhromaždovali do velkých niekol'kotisícových skupín a pod velením svojich kniežat alebo náčelníkov sa stávali vážnymi spojencami Turkov, ktorí sa snažili o udržanie svojho vplyvu na Kaukaze (Bobrovskii 1893, 26).

Rusko sa upevnilo na severnom Kaukaze a čoskoro začalo postupovat na juh od kaukazského chrbta, avšak Čerkesi na západe a Čečenci na východe sa postavili proti ruskej centralizačnej politike. Začala Kaukazská vojna $(1817-1864)^{18}$ a v jej prvej etape zohrali dôležitú rolu nasledovníci Čečenca šejcha Mansura, predchodcu známeho Šamila. Ten ešte na konci 18. storočia vyhlásil Rusom svätú vojnu - džihád a viacerí vojenskí náčelníci Čečenska, Kabardy a Čerkeska, nespokojní s Ruskom alebo predtým nerozhodní v religióznom aspekte, prijali islam. V boji s protureckými moslimami šejcha Mansura kabinet cárovnej Kataríny II. Vel'kej (1762 - 1796) stavil na Petrohrade lojálnych povolžských moslimov (tatárske obyvatel'stvo). Táto politika pokračovala aj pri jej nasledovníkoch. Napríklad v roku 1840 tajomník Kabardského dočasného súdu žiadal velitela ruských vojsk gen. Grabeho poslat na Kaukaz „osvietených a dobre zmýšlajúcich“ moslimských duchovných, najmä z Kazane a Buchary. „Aby tu na mieste a otvorene v mešitách mohli odsúdit Šamila a jeho nasledovníkov z falošnej interpretácie Koránu. "Paradoxne ruská administratíva začala vytvárat moslimské duchovné správy, pričom sa medzi pravoverných začali hlásit aj rody, $\mathrm{v}$ ktorých sa ešte zachovali (silne zmiešané s pohanstvom a islamom) pravoslávne tradície (Gumanov 2011). Na konci 17. - začiatkom 19. storočia krestanstvo definitívne mizne z Čečenska,

17 Rusko-osmanská mierová zmluva uzavretá v Küçük Kaynarca (dnes Kajnardža v Bulharsku) 21. júla 1774.

18 Všeobecný názov vojenských operácií ruskej armády v súvislosti s pripojením horských oblastí Severného Kaukazu k Ruskému impériu a vojenskou konfrontáciou so Severokaukazským imamátom (Imamátom Šamila). Kaukazská vojna sa prelínala s rusko-perzskou (1826 - 1828) a rusko-osmanskou vojnou (1828 129), resp. Krymskou vojnou (1853 - 1856). 
pravoslávnymi ostanú len Osetsko a čiastočne Kabarda. Až v roku 1880 na podnet Svätej Synody bol založený Spolok obnovenia pravoslávneho krestanstva na severnom Kaukaze a v roku 1885 bola organizovaná Vladikaukazská eparchia Ruskej pravoslávnej cirkvi (do roku 1894 - v rámci gruzínskeho exarchátu) (Pravoslavie 2011,21).

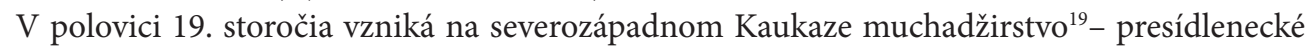
hnutie vel'kej časti moslimského obyvatel'stva Kaukazu do Osmanskej ríše, ktoré bolo odpovedou na vojensko-politické metódy pripojenia regiónu do Ruského impéria (Dudarev 2017, 527). Podla niektorých názorov - masové rozmery tohto presídleneckého hnutia kaukazských horalov bolo spôsobené radikálnou zmenou charakteru boja s nimi - od organizácií expedícií ruská administratíva prechádza do systematického vysídlenia Čerkesov a osídlenia dobytých teritórií ruskými kolonistami. Avšak je zrejmé, že k presídleniu takých rozmerov prispeli - okrem náboženských faktorov (islam verzus pravoslávie) - aj dôsledky zrušenia nevolníctva v Ruskom impériu v roku 1861. Pre čast' severokaukazských národov bola strata nevolníkov a otrokov proste mentálne neprípustná, a tak situáciu riešili odchodom na územie Osmanskej ríše. ${ }^{20}$

Na konci Kaukazskej vojny ruská vláda vzniesla ultimátum o vysídlení moslimských horských národov východného Čiernomoria. Mali možnost' presídlit sa bud' do kubáňskych stepí, alebo do Osmanskej ríše. S Portou boli v tomto smere uzavreté príslušné dohody (Volkova 1974, 219-220; Fadeev 1889, 67-69). Zvlášt zložito prebiehalo presídlenie v novovytvorenom Zakubáňskom kraji, kde v strategicky dôležitých rajónoch severozápadného Kaukazu spolu s Abcházcami a Ubychmi žili prímorské etnické skupiny Natuchajcov, Šapsugov, Abadzechov atd'.

Samotné presídlenie horských národov čiernomorského pobrežia Kaukazu na teritórium Osmanskej ríše - tzv. čerkeské muchadžirstvo, kulminovalo v rokoch 1858 - 1865 a realizovalo sa v niekolkých etapách - po živelnom presídlení nabralo organizovaný charakter (presídlenia však prebiehali aj pred rokom 1858 a po roku 1865 - prakticky do I. svetovej vojny). V roku 1862 vznikla špeciálna „Komisia pre presídlenie horalského obyvatel'stva do Turecka“, ktorá bola oprávnená organizovat presídlenie horalov severného Kaukazu, zabezpečit ich peňažnými dávkami (10 strieborných rublov na rodinu) a rokovat’ o preprave emigrantov do Osmanskej ríše s vlastníkmi prepravných lodí (Berzhe 1882, 298). Čerkesi boli pod konvojom deportovaní na čiernomorské pobrežie, následne prevážaní lod’ami na maloázijské pobrežie a osmanskou vládou dalej rozsídlovaní v malých skupinách do rôznych častí ríše (čiastočne na území Anatólie, sýrsko-palestínskej oblasti, väčšinou však na Balkánsky polostrov, hlavne do Bulharska).

Odhaduje sa, že štvrtina obyvatel'stva horalov severozápadného Kaukazu bola presídlená na Kubáň a tri štvrtiny do Malej Ázie, pričom Šapsugovia a Ubychovia odišli takmer všetci, z Kabardincov, Abadzechov a Bžeduchov - minimálne polovica. Podla niektorých (zdaleka neúplných) údajov v rokoch 1859 - 1862 bolo z Vel'kej Kabardy vysídlených do Turecka viac ako 10 tis. ludí, do 3 tis. tagaurských a digorských Osetov, v roku 1865 - približne 3 tis. Kabardov a 45 osetských rodín. V roku 1864 bolo vystahovaných asi 6 tis. Šapsugov, viac ako 21 tis. Ubychov, až 20 tis. Bžeduchov a Abadzekov, asi 400 rodín Karačejcov a v 80. rokoch a v rokoch 1905 - 1906 počet

19 Muchadžirstvo (rus. мухаджирство, махаджирство; arab. انورجاهن cia) - vo všeobecnosti masové a cielené presídlenie moslimov do moslimskej krajiny z nemoslimského štátu, pokial' sú v menšine (napr. v dôsledku anexie moslimskej krajiny krestanským štátom) a neželajú si zmierit’ sa s menšinovým postavením.

20 Svedčí o tom napríklad nasledujúca skutočnosț. Dňa 4. augusta 1866 predstavitelia staršiny Džigetov z gagrinskej osady prišli za ruským velitelom gagrinskej pevnosti Bertom de Lagardom a oznámili svoje rozhodnutie prestahovat’ sa do Osmanskej ríše. K presídleniu Džigetov „do Turecka podnietilo vyhlásenie okružného velitela, že im odoberú všetkých rolníkov a otrokov a kvôli tomu ostanú bez pracovných rúk, a tým aj bez prostriedkov živobytia. Hoci v Turecku bude t’ažko, budú však mat'svojich rolníkov a otrokov, ktorí im prácou svojich rúk zabezpečia obživu" (Cherkasov et al. 2015, 891). 
Karačejcov-muchadžirov bol asi 13 - 15 tisíc ludí (Tishkov 2007, 48). Podla súčasných odhadov do Osmanskej ríše bolo presídlených 350000 až 450000 ludí, hoci sa vyskytujú aj ovela väčšie údaje - 500 tis. až 900 tis. horalov. Etnicky „vyčistené“ územie severozápadného Kaukazu sa medzitým osídlovalo ruskými kozákmi, Arménmi a obyvatel'stvom z centrálnych častí Ruského impéria. ${ }^{21}$

Cielená činnost’ Ruskej pravoslávnej cirkvi v smere obnovenia krestanstva v regióne, ako už bolo uvedené vyššie, sa začala v polovici 18. storočia. Podmienky na to boli kvalitatívne odlišné $\mathrm{v}$ periodicky sa meniacom období mieru a vojen na Kaukaze (najmä v období Kaukazskej vojny). Posledná perióda christianizácie - v poslednej tretine 19. storočia - do roku 1917, bola spojená s činnostou nielen cirkevných štruktúr, ale aj cirkevno-svetských verejných organizácií, ktoré si stanovili za ciel' obnovenie a upevnenie pravoslávneho krestanstva v regióne (Savenko 2011, 252-253).

Ked’ sa v roku 1917 Ruské impérium zrútilo, na území Severného Kaukazu došlo k pokusu zorganizovat tzv. Horskú republiku (1917 - 1918). Vlajka Horskej republiky, ktorej prvky je dnes možné vidiet’ na štátnej vlajke Abcházska, pozostávala zo striedajúcich sa troch bielych a štyroch zelených pruhov. Tri biele pruhy symbolizovali pravoslávne Abcházsko, Kabardu a Osetsko a štyri zelené pruhy - moslimské Čerkesko, Karačajevsko-Balkarsko, Čečensko a Dagestan. Už len takýto prístup separatistov evidentne naznačoval rešpektovanie historických tradícií jednotlivých krajín regiónu a tradícií predkov, čo z hladiska mentality horských národov Kaukazu je rozhodne významné (Pravoslavie 2011, 21).

\section{REFERENCES}

Alekseev, Valeriy. 2006. Авиатар и Сидония. Грузинские святые из еврейской диаспоры [Aviatar and Sidonia. Georgian saints from the Jewish diaspora]. In Истина и жизнь [Truth and life], 4/2006, 1-4.

Alekseeva, Evgeniya Pavlovna. 1959. Очерки по истории черкесов в XIV - XV вв. [Essays on the history of the Circassians in the XIV - XV centuries]. In Труды Карачаево-черкесского научно-исследовательского института. Vyp. III. [Proceedings of the Karachay-Circassian Research Institute. Vyp. III]. Cherkessk, 19-24.

Aleš, Pavel. 1978. Cirkevné dejiny I. Prešov.

Alyshov, N.A. 2018. Христианство в Азербайджане. XI-XXI вв. [Christianity in Azerbaijan. XIXXI centuries]. In Религии Центральной Азии и Азербайджана. Том IV. Христианство [Religions of Central Asia and Azerbaijan. Volume IV. Christianity]. - Samarkand.

Bell, James. 2007. Дневник пребывания в Черкесии в течение 1837 - 1839 годов. В 2 т. Т. 1. [Journal of a residence in Circassia during the years 1837-1839. In 2 t. T. 1]. Nalchik.

Berzhe, Adolf. 1882. Выселение горцев с Кавказа [Eviction of mountaineers from the Caucasus]. In Русская старина [Russian antiquity], T. 36, No 10-12. St. Petersburg, 1-32.

Bobrovskii, P.O. 1893. Kubanskii egerskii korpus 1786 - 1796 gg. [The Kuban Jaeger corps 17861796]. St. Petersburg.

Čerkasov, Aleksandr et al. 2014. Nobilita a lud ubyšskej spoločnosti: príčiny sociálneho konfliktu. In Acta historica Neosoliensia 17/1-2, 268-280.

${ }_{21}$ Súčasné výskumy nenechávajú na pochybách, že deportácie kaukazských horalov boli rusko-osmanským projektom, prospešným pre obe strany. Ruské impérium získalo úrodné a strategicky významné územia a zbavilo sa časti moslimského obyvatelstva, ktoré odmietalo ruskú prítomnosṫ v regióne. Osmanská ríša získala zdravú populáciu s rozvinutými tradíciami vojenskej kultúry, ktorú osídlovala najmä v balkánskych provinciách Porty, kde plnili úlohu živého pohraničného plotu medzi krestanským obyvatelstvom (Nefliasheva 2011). 
Dudarev, Sergey L. 2017. On the Question of the Terms «Muhajirun» and «Muhajirism» In Bylye Gody 44(2), 525-532.

Eliashvili, Natan. 1926. История грузинских евреев [History of Georgian Jews]. Tiflis.

Encyklopedicheskiy slovar. 1903. Энциклопедический словарь Брокгауза и Ефрона [Encyclopedic Dictionary of Brockhaus and Efron]. T. XXXVIIIa: Черкесы [Circassians]. St. Petersburg, 580-582.

Fadeev, Rostislav Andreevich. 1889. Дело о выселении горцев. Закатальское восстание. Часть II. Собрание сочинений. [The case of the eviction of the highlanders. Zagatala Uprising. Part II. Collected Works]. T. I. St. Petersburg, 61-76.

Farzaliev, Soltan. 2008. Распространение иудаизма на Кавказе: исторический очерк [The spread of Judaism in the Caucasus: a historical outline]. In: Кавказ \& глобализация [Caucasus \& globalization], T. 2, vyp. 4, 168-178.

Geyushev, Rashid. 1984. Христианство в Кавказской Албании [Christianity in Caucasian Albania]. Elm.

Golden, Peter B. 2007. Khazar studies: achievements and perspectives. In The World of the Khazars: New Perspectives. Brill, 7-58.

Gorskie evrei. 1999. Горские евреи: История, этнография, культура [Mountain Jews: History, Ethnography, Culture]. Moscow.

Gumanov, Mikhail. 2011. Православный Кавказ - утопия или перспектива? [Orthodox Caucasus - Utopia or Perspective?] In: Pravda.ru, 24. 3. 2011.

https://faith.pravda.ru/1071329-caucasus/

Cherkasov, Aleksandr A. et al. 2015. Jikis and Jiketi in Conditions of War and Peace (1840-1860 years). In Bylye Gody 38/4, 888-893.

Cherkasov, Aleksandr A. et al. 2016. The evolution of christianity in the Caucasus in the IV-XVIII centuries. In Bylye Gody 40/2, 382-391.

Cherkasov, Aleksandr A. et al. 2018. The Circassian aristocracy in the late XVIII - The first half of XIX centuries: The social structure of society. In Bylye Gody 47/1, 88-96.

Ioseliani, Platon. 1843. Краткая история грузинской церкви [A brief history of the Georgian church]. St. Petersburg.

Istoriya evreev na Kavkaze. История евреев на Кавказе [History of Jews in the Caucasus]. In Еврейская Энциклопедия [Jewish Encyclopedia].

https://toldot.ru/articles/articles_1931.html

Ivanič, Peter - Lukáčová, Martina. 2014. Historicko-geografický kontext misií solúnskych bratov (Cesty Sv. Konštantína-Cyrila a Metoda do roku 867) [Historical-Geographical Context of the Solun Brothers' Missions (Journeys of Sts. Constantine-Cyril and Methodius until 867)]. In Konštantínove listy [Constantine's Letters] 7/1, 2-13.

Kavkaz. 2010. Кавказ: европейские дневники XIII - XVIII веков [Caucasus: european diaries of the XIII-XVIII centuries] Ed. V. Atalikov. Vyp. III. Nalchik.

Lyulie, Leonid Yakovlevich. 1990. Черкессия: Историко-этнографические статьи [Circassia: historical and ethnographical articles]. Severo-Kavkazskii filial MTsTK «Vozrozhdenie».

Montpérreux, Frédéric Dubois de. 2010. Путешествие вокруг Кавказа. Т. 1. У черкесов и абхазов. [Travel around the Caucasus. T. 1. The Circassians and Abkhazians]. Maikop.

Nefliasheva, Nauma. 2011. Миграции с Северного Кавказа вчера и сегодня. Мухаджиры [Migrations from the North Caucasus yesterday and today. Muhajirs]. In Кавказский узел [Caucasian Knot].

https://www.kavkaz-uzel.eu/blogs/1927/posts/6454.

Otechestvennaya istoriya. 1994. Отечественная история: энциклопедия [National History: Encyclopedia]. In 5 t. T. 1. Moscow. 
P.U. 1869. Начало христианства в Закавказье и на Кавказе [The beginning of christianity in Transcaucasia and the Caucasus]. In Сборник сведений о кавказских горцах [Collection of information about the Caucasian highlanders] 2/1869. Tiflis, 1-24.

Petrushevskiy, Ilia Pavlovich. 1949. Очерки по истории феодальных отношений в Азербайджане и Армении в XVI - начале XIX вв. [Essays on the history of feudal relations in Azerbaijan and Armenia in the 16th - early 19th centuries]. Leningrad.

Pfaff, V. B. 1871. Материалы для истории осетин [Materials for the history of the ossetians]. In Сборник сведений о кавказских горцах [Collection of information about the Caucasian highlanders]. Vyp. 5. Tiflis, 1-100.

Pravoslavie. 2011. Православие на Северном Кавказе [Orthodoxy in the North Caucasus]. In Православная газета [Orthodox newspaper] 37(646), 21.

Savenko, Elena Aleksandrovna. 2011. Вопросы периодизации распространения и восстановления христианства на Северном Кавказе [Issues of periodization distribution and recovery of christianity in the North Caucasus]. In Проблемы и перспективы исследования церковной истории Северного Кавказа. Вып. 2. [Problems and prospects of research of the church history of the North Caucasus. Vol. 2]. Stavropol, 238-255.

Shcherbina, Fedor Andreevich. 1916. История Арвамира и черкесогаев [History of Arvamir and the Cherkesogai]. Ekaterinodar.

Spenser, Edmund. 2008. Описание поездок по западному Кавказу, включая путешествие через Имеретию, Мингрелию, Турцию, Молдавию, Галицию, Силезию и Моравию в 1836 г. [Description of trips in the western Caucasus, including the journey through Imereti, Mingrelia, Turkey, Moldova, Galicia, Silesia and Moravia in 1836]. Nalchik.

Szabo, Miloš. 2016. Východní křestanské cirkve. Praha.

Šmigel', Michal et al. 2017. Život a zvyky kaukazských Čerkesov: historicko-komparatívna sondáž cestopisov európskych cestovatelov od začiatku 16. do polovice 19. storočia. In Muzeológia a kultúrne dedičstvo 5/2, 29-50.

Tishkov, Valeriy. 2007. Социально-политическая история Северного Кавказа [Socio-political history of the North Caucasus]. In Tishkov, V. (ed.). Российский Кавказ. Книга для политиков [Russian Caucasus. Book for politicians]. Moscow, 17-72.

Tornau, Fedor Fedorovich. 2008. Воспоминания кавказского офицера. В двух частях. [The memoirs of a Caucasian officer. In two parts]. Maikop.

Tsagareli, Aleksandr Antonovich. 1891. Сношения России с Кавказом в XVI - XVIII вв. [Relations of Russia with the Caucasus in the XVI - XVIII centuries] St. Petersburg.

Vasiliev, Aleksander Aleksandrovich. 1936. The Goths in the Crimea. Cambridge.

Vinogradov, V. B. 1995. Средняя Кубань. Земляки и соседи [Middle Kuban. Fellow countrymen and neighbors]. Армавир, 1995 - Часть «Армяне закубанские» [Arvamir, 1995 - Part «The Armenians of Kuban»].

http://budetinteresno.narod.ru/kraeved/narod_vin_cherkeso_gai.htm

Volkova, Natalia. 1974. Этнический состав населения Северного Кавказа в XVIII - начале $\mathrm{XX}$ в. [The ethnic composition of the population of the North Caucasus in the XVIII - early XX centuries]. Moscow.

Voroshilov, Vladimir Ivanovich. 2008. История убыхов [History of Ubykhs]. Maikop.

SUMMARY: METAMORPHOSIS OF CHRISTIANITY IN THE CAUCASUS: FROM ITS EXPANSION TO THE INTEGRATION OF THE REGION TO THE RUSSIAN EMPIRE IN THE 19TH CENTURY. The Caucasus is in its generality a historically unique region. It has a multinational, religiously diverse and multicultural character. It acquired such 
attributes because of a peculiar historical development. In the Caucasus, civilizations have met since ancient times and was regarded a kind of "ethnic chessboard" of nations that alongside their culture - were also bearers of their own religious beliefs and manifestations of the religious culture of the people. The history of particular religions in the Caucasus (paganism, Judaism, Christianity, Islam) is very interesting and their co-existence attracts the attention of scientific interest. Presented comparative-historical study attempts to map not exactly the genesis of Christianity in the Caucasus, but rather its metamorphic display in the context of the overall religiosity and dialogue of civilizations in this region. It is also entitled to have another attribute - the crossroad of cultures. Christianity itself, since its establishment in the Caucasus in the 4th century, went through periods of its very start, standing out, decline and downfall across all ethnic groups of the region under the influence of internal, but especially external factors. Christianity had its own history for each of the nations of the Caucasus. Specific of the metamorphosis of Christianity in the Caucasus was not only syncretism or the pressure of Islam, but also the presence of the conservative mentality of Caucasian mountain dwellers, where traditional way of life, freedom and independence were valued.

doc. PhDr. Michal Šmigel', PhD.

Matej Bel University in Banská Bystrica

Faculty of Arts

Department of History

Tajovského 40,

97401 Banská Bystrica

Slovakia

michal.smigel@umb.sk

doc. Aleksandr A. Cherkasov, DrSc.

Volgograd state university

100 University Ave.

400062 Volgograd

Russian Federation

International Network Center for Fundamental and Applied Research

1150 Connecticut Ave. NW

STE 900 Washington

District of Columbia, 20036

USA

incfar.center@gmail.com

doc. PaedDr. Miroslav Kmet', PhD.

Matej Bel University in Banská Bystrica

Faculty of Arts

Department of History

Tajovského 40

97401 Banská Bystrica

Slovakia

miroslav.kmet@umb.sk 